\title{
Ordforklaringer
}

C-reaktivt protein (CRP) frigjøres fra leveren ved inflammasjon. I forskning brukes høysensitiv deteksjon, dvs. i området < 5 mg/l.

Neopterin frigjøres fra aktiverte monocytter/makrofager og er en markør for plakkaktivitet og prediktor av forskjellige typer koronare hendelser.

HUNT-1 er den første Helseundersøkelsen i Nord-Trøndelag. Den ble gjennomført i perioden 1984-86. Alle innbyggerne i Nord-Trøndelag ble invitert, og $88,1 \%$ deltok. Studien besto av en klinisk undersøkelse og spørreskjemaer. Serumet i denne studien er det eneste biologiske materialet fra HUNT-1.

\section{Neopterin predikerer hjertedød ved diabetes}

\author{
Neopterin, en markør for monocyttaktivering, er en god prediktor \\ for iskemisk hjertedød hos diabetespasienter. Det viser en studie \\ fra Helseundersøkelsen i Nord-Trøndelag.
}

Aterosklerose er en inflammatorisk prosess, og inflammasjonsmarkører er potensielle prediktorer for iskemisk hjertesykdom. Personer med diabetes har forhøyet risiko for utvikling av iskemisk hjertesykdom og forskningsgruppen for aterosklerose og inflammasjon ved Norges teknisk-naturvitenskapelige universitet har unders $\varnothing \mathrm{kt}$ diabetikere $\mathrm{i}$ en studie som er publisert i tidsskriftet Atherosclerosis (1).

- Hypotesen vår er at diabetes og aterosklerose har inflammasjon som felles patologisk mekanisme, slik at det å ha diabetes forverrer den aterosklerotiske prosessen ved å $\varnothing \mathrm{ke}$ inflammasjonen, sier Inga Vengen, som er artikkelens førsteforfatter.

Neopterin og C-reaktivt protein (CRP) ble analysert i serum fra 200 diabetikere og 198 kontrollpersoner som deltok i den første Helseunders $\varnothing$ kelsen i Nord-Trøndelag (HUNT) i 1980-årene. Resultatene ble koblet sammen med opplysninger om iskemisk hjertedød fra dødsårsaksregisteret i 2004. Overlevelsesanalyser viste at både neopterin (hasardrate 2,59; $95 \% \mathrm{KI}$ 1,11-6,01) og CRP (hasardrate 2,45; $95 \%$ KI 1,05-5,69) var uavhengige prediktorer for iskemisk hjertedød i gruppen med diabetes, men ikke i kontrollgruppen.

- Neopterin frigjøres fra aktiverte makrofager blant annet $\mathrm{i}$ aterosklerotiske plakk, og man kan tenke seg at den kan være en mer spesifikk prediktor enn CRP, som er en mark $\varnothing \mathrm{r}$ for uspesifikk lavgradig betennelse. Vår konklusjon er at de to markørene gjenspeiler forskjellige aspekter av den underliggende patogenesen for koronarsykdom hos diabetikerne. Materialet er unikt med tanke på den lange observasjonstiden. Dessverre er det ganske lite, og vi planlegger derfor en tilsvarende studie i HUNT-2, sier Vengen.

\section{Forskning på aterosklerose og inflammasjon}

Artikkelen er skrevet av Inga Vengen, Ane Cecilie Dale, Rune Wiseth, Kristian Midthjell og Vibeke Videm. Inga Vengen har gått på forskerlinjen og er nå ph.d.-stipendiat ved Norges teknisk-naturvitenskapelige universitet. Professor Vibeke Videm er hovedveileder. De arbeider sammen med Rune Wiseth, som er biveileder, og Ane Cecilie Dale i forskningsgruppen for aterosklerose og inflammasjon. Kristian Midthjell arbeider ved HUNT og var initiativtaker og pådriver for innsamling av dette materialet med over 20 års observasjonstid. Nylig publiserte de samme forfatterne en artikkel om laktoferrin, som også er en prediktor for iskemisk hjertedød hos diabetikere (2).

\section{Erlend Hem}

erlend.hem@medisin.uio.no

Tidsskriftet

\section{Litteratur}

1. Vengen IT, Dale AC, Wiseth R et al. Neopterin predicts the risk for fatal ischemic heart disease in type 2 diabetes mellitus: long-term follow-up of the HUNT 1 study. Atherosclerosis 2009; 207. $239-44$.

2. Vengen IT, Dale AC, Wiseth R et al. Lactoferrin is a novel predictor of fatal ischemic heart disease in diabetes mellitus type 2: long-term follow-up of the HUNT 1 study. Atherosclerosis 2010; 212: $614-20$.
Laktoferrin frigjøres fra nøytrofile granulocytter ved degranulering.

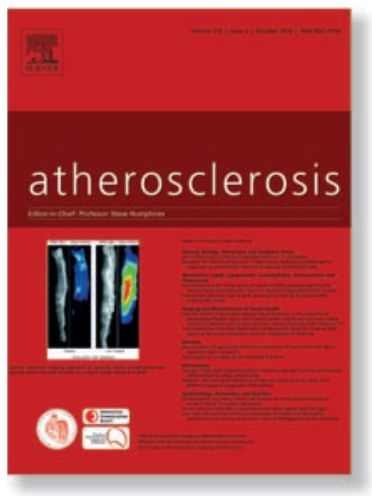

Artikkelen er publisert i det velrenommerte tidsskriftet Atherosclerosis (http://atherosclerosis-journal.com) 